


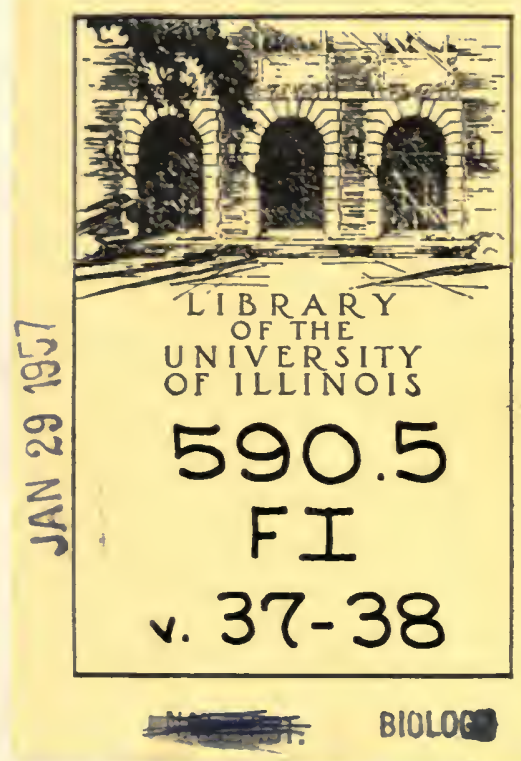


The person charging this material is responsible for its return on or before the Latest Date stamped below.

Theft, mutilation and underlining of books are reasons for disciplinary action and may

result in dismissal from the University.

UNIVERSITY OF ILLINOIS LIBRARY AT URBANA-CHAMPAIGN

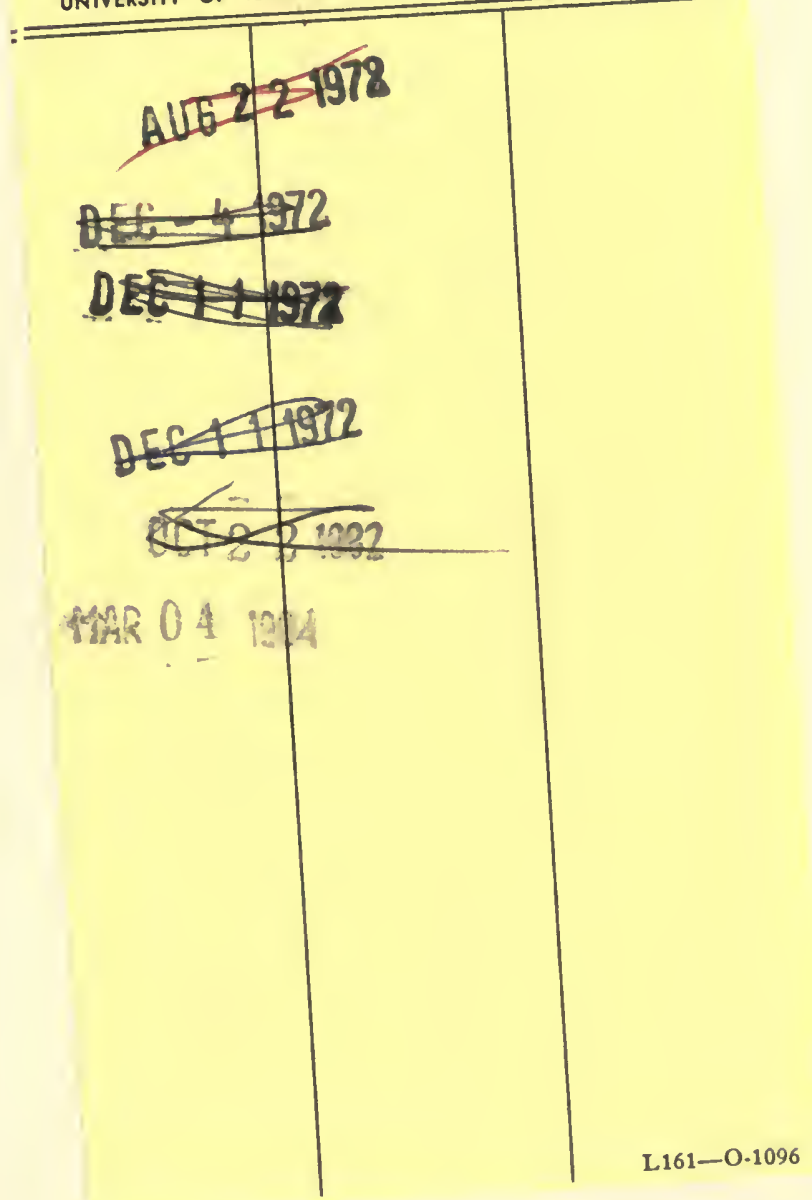







\title{
Palestinian Species and Races of Jaminia Risso (Mollusca; Gastropoda)
}

\author{
GEORG HAAS ${ }^{1}$ \\ Field Associate, Department of Zoology
}

The number of species of the gastropod Jaminia occurring in Palestine is strikingly high. Despite the diversity of biotopes in this region only the following few types of habitat are absolutely devoid of species of Jaminia: the area of pure loess in the south (the Negev), the hot lower Jordan Valley, and the shores of the Dead Sea; they are also absent from deep alluvions of earth devoid of rocky inclusions, and regions of basaltic rocks (upper Jordan Valley). An abundance of specimens can be found in the central hills (limestone), though there is a striking scarcity in variety and number on the eastern escarpment of the Jordan Valley, south of the Sea of Galilee. Certain species may be found in the area of solidified dunes and sandstone along the coast. Even in the very arid southern parts of the country Jaminia occurs wherever there is rocky ground. These various areas differ greatly in annual rainfall and floral character. As a whole, the genus shows a remarkable ability to endure very dry conditions (an annual rainfall of about 100-150 cm. for J. heptodon, for instance).

There are apparently many inaccuracies in the taxonomic literature on this genus, and many forms described as valid species are doubtful. I am aware that the restriction of my collecting activities to a limited area is a serious handicap. Our knowledge of the fauna of Transjordan is very limited, and even the species described from Syria and Lebanon do not give a comprehensive picture. Another difficulty is that many forms could not be found alive, although they occur regularly in the drift of various rivers. It will therefore be necessary to give a brief description of several forms whose systematic significance cannot be definitely assessed, the more so since intergrading specimens are frequent. On the other hand, I shall attempt

${ }^{1}$ Hebrew University, Jerusalem, Israel. 
to give a true account of the striking variations in size and proportions that are found even in the best-known and established species, such as Jaminia (Chondrula) septemdentata and J. (Jaminia) saulcyi.

The material on which the following study is based was collected mostly by the author, and is kept in the Department of Zoology of the Hebrew University. It is referred to in the text as HUJ. Representatives of all the species involved, from a great number of their known localities, have been presented to Chicago Natural History Museum, which also possesses the collection of Jaminia gathered by Fritz Haas throughout Israel in the spring of 1954 . Thus, the species and races treated in this study are well represented in at least one large museum in the New World.

All figures illustrating this report were made with an Abbé drawing apparatus.

\section{Key to SPECIES}

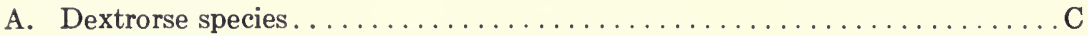

B. Sinistrorse species. . . . . . . . . . . . . . . . . . . . . D

C. Section Chondrula.

Seven or eight whorls.

Aperture with seven teeth, parietal teeth two, more or less coalescent, shape oviform to elongate, shell more or less dark. . septemdentata Roth

Aperture with seven teeth, outer parietal tooth very small or vestigial, shell whitish in the lower whorls, yellow on the apex, more or less

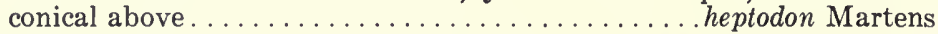

Smaller than the previous ones, shell dark brown, angular teeth more or less vestigial, shape conical.................. libanica Naegele

Six whorls.

Small ( $5 \mathrm{~mm}$.), globular, six teeth (none on the callus) . . ovularis Olivier

Small, ovoid-globular, both lip teeth with a fissure on the summit.

sulcidens Mousson

Small, elongate, one parietal tooth that extends inward.

lamellifera Rossmaessler

Small to medium $(8.5 \mathrm{~mm}$.), basal tooth absent. . . . . sexdentata Naegele

D. Section Jaminia.

Dark brown, $7 \frac{1}{2}-8$ whorls, more or less conically elongate, teeth as in septemdentata.........................chondriformis Mousson

Shell ovoid, resembling septemdentata .......... saulcyi Bourguignat

Jaminia (Jaminia) saulcyi Bourguignat. Figure 97.

Bulimus saulcyi Bourguignat, 1852, Testa novissima ... p. 18; 1853, Catalogue raisonné ..., p. 42, pl. 2, figs. 4, 5 .

Description.-Shell ovoid, resembling Jaminia (Chondrula) septemdentata if seen in a mirror, but suture more slanting; seven whorls. Aperture with six or seven denticulations: two labial folds; 
two columellar folds, the lower (angular) one less prominent, the upper one inserted higher; two parietal folds, the middle one stronger, opposite the lower palatal fold, the angular one small, more or less well developed. Color gray, often with a reddish brown hue; last
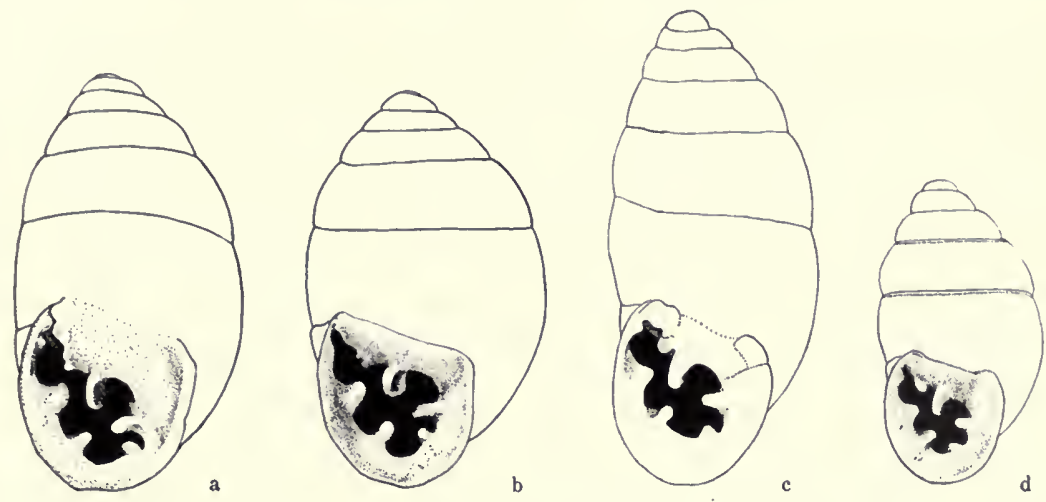

FIG. 97. Jaminia (Jaminia) saulcyi Bourguignat. a, length $9.3 \mathrm{~mm}$., from Ahuza near Haifa; moderately elongate shell. $b$, length $8.5 \mathrm{~mm}$., from Shefeja; large globular type. $c$, length $8 \mathrm{~mm}$., drift of Jarmuk River, probably of Syrian origin. $d$, length $6.5 \mathrm{~mm}$., drift of Dead Sea at north end at Kallia. All approximately $\times 5$.

whorl whitish, aperture white. In the typical form the columellar teeth are very closely set.

Localities.-Syria (Westerlund). Khan el Bedaouieh near Nazareth (Bourguignat), Tiberias (Kobelt), near Tiberias and Saida (Mousson, very common), hills near Tyre (Tristram), Djenin (Barrois), Haifa (F. Lange in O. Boettger). "Collines entre Néelin et Beit Naleala, districte de Jaffa" (Nalin and Beth Nabala; Germain).

To these I can add: Ginegar and Sarid, western Emek Jesreel, Kabara-Shuni near Binjamina; Athlith; between Safed and Akko, Hunin, Nebi Usha, Hule-area, Ain Melaha, Wadi Handaj; Shegeya, Wadi Fallah, Jearoth Hacarmel (all in Carmel area); Nazareth; Mount Gilboa; El Hamme (southeast of Lake Tiberias); in the drifts of the Jarmuk, the Jordan, and the Dead Sea.

These localities are mostly in the northern portion of Palestine, that is, in Galilee, in the Carmel area and its southern foothills, and in Samaria (Djenin). Near Athlith the species reaches the rocky seashore. Nalin-Beth Nabala, in the foothills of the central ridge, is the southern limit of the species. Westerlund (fide Mousson) describes a var. impressus from Jerusalem, a most unlikely locality. 
A rather continuous area of distribution north of the Emek Jesreel, through Lower and Upper Galilee, seems fairly established. There is also a region of unknown extension south of the Emek (Djenin, Mount Gilboa) and the Carmel area. As far as the distribution in Transjordan is concerned, the dense population of El Hamme is noteworthy. As the drift of the Jordan often contains very small specimens of unknown origin, a larger area of distribution, reaching into the neighboring countries, must be assumed. The isolated locality Nalin-Beth Nabala indicates a large extension of the range south of the margin of the central ridge.

It is not easy to understand this distribution ecologically. The annual rainfall of all these places is rather high (above $600 \mathrm{~mm}$.) with the exception of El Hamme, where a permanent river, the Jarmuk, compensates for the lack of rain (400-500 mm.). The slopes of the lower Jordan Valley and the arid South are unsuitable for this species, as is the coastal plain south of the Carmel, where dunes but no solid limestone rock is found. We have no clear idea as to the southern limit of distribution, which should run somewhere across the central hills. The absence of this species in the Jerusalem area and farther south cannot be explained by lack of precipitation, but perhaps by too low minimum temperatures due to higher altitude. All known localities are below 400 meters above sea level (Nazareth), most of them near the shore or under 150 meters.

Westerlund gives 9-10.5 $\times 4.5-5 \mathrm{~mm}$. as the size of this species. The largest specimens from Palestine in our collection have a length of $9.3 \mathrm{~mm}$. (Carmel area, Ahuza, fig. 97, a). These were, incidentally, found together with rather large specimens of septemdentata. Another shell of similar size, found in the drift of the Jarmuk River, is probably a Syrian specimen (fig. 97, c). Palestinian specimens are, as a rule, about $8.5 \mathrm{~mm}$. long and often rather globular (fig. $97, b)$. The length-width ratio varies considerably, as may be seen by comparing our figures. The smallest specimen, $6.5 \mathrm{~mm}$. long (fig. 97, d) and of unknown provenience, was found in the drift of the Dead Sea near its northern end at Kallia. It might be compared with Mousson's var. impressus, described as follows (p. 47 of reprint): "Minor, $7 \times 3 \mathrm{~mm}$, elongato-ovalis, margine sinistro extus impresso, dentibus columellae minus approximatis, dente infero marginis liberi retro plicam elongatam, extus per totum primum anfractum perspicuum, emittente."

I am sceptical as to the correctness of Mousson's locality, "environs de Jerusalem." As the true habitat of my specimen is 
equally uncertain, it cannot yet be determined whether this variety represents small individual variants or a whole group, of taxonomic significance. That Pollonera's specimens from Nalin-Beth Nabala $(6 \times 3 \mathrm{~mm}$.) belong to the same variety might be concluded both from their minute size and from the peripheral locality. Confusion of this variety with $J$. chondriformis seems very likely.

\section{Jaminia (Jaminia) chondriformis Mousson. Figure 98.}

Pupa chondriformis Mousson, 1861, Vierteljahrschr. naturf. Ges. Zürich, 6: 49.

Buliminus (Euchondrus) chondriformis Boettger, 1883, Ber. Offenb. Ver. Naturk., 22: 173.

Chondrula Massei Pallary, 1939, Mém. Inst. Égyptien, 12: 48, pl. 3, figs. 49-51.

Mousson's original description is as follows: “Testa sinistrorsa, rimato-perforata, conico-elongata, vix striatula, pellucida, glabra, oleaceo-cornea. Spira conoidea, summo acutiusculo; sutura tenuissime albo-marginata. Anfractus 71/2, convexi, ultimus antice paulo ascendens, ad basin subcompressus. Apertura verticalis, ovatotriangularis, 7-dentata: duobus columellaribus, supero medio, infero basali obsoleto; duobus in margine externo, distantibus et aequalibus, vix immersis retro in plicas exeuntibus. Perist. expansiusculum, album, vix labiatum; marginibus ad basin subangulatim junctis, columellari recto." In this description Mousson states that his species has seven teeth, but he mentions only six: two parietals of unequal size, two columellars of unequal size, and two equal teeth on the outer border. The seventh tooth should be, as in septemdentata, the little tubercle at the insertion of the external border.

Pallary (1939) gives a rather inaccurate description of his new Chondrula Massei: “L'ouverture est ornée d'un petit pli, d'une lamelle très oblique et de deux autres lamelles, toutes trois à l'intérieur de la paroi columellaire, de deux denticules sur las paroi palatale et d'un très petit bourrelet à l'insertion. En somme six excroissances peu saillantes."

The number of denticles on the columellar border is four, not three, if the "petit pli" is taken into consideration and if Pallary's columellar border includes the parietal wall also, as I conclude from comparing his description with his rather indistinct pictures; his figures 49 and 51 show clearly, however, two palatal teeth and three denticulations on the parietal wall. The uppermost at the insertion is probably Pallary's "bourrelet," and the other two are, as in septemdentata, of very different size, the right one being more than twice as large as the left. Figure 51 of Pallary shows a very promi- 
nent slanting tooth on the columellar border. In his figure 50 it is very indistinct, however. If the listing of the teeth is meant to begin at the angular tooth on the parietal wall and to proceed toward the insertion, then the identity of Massei and chondriformis would
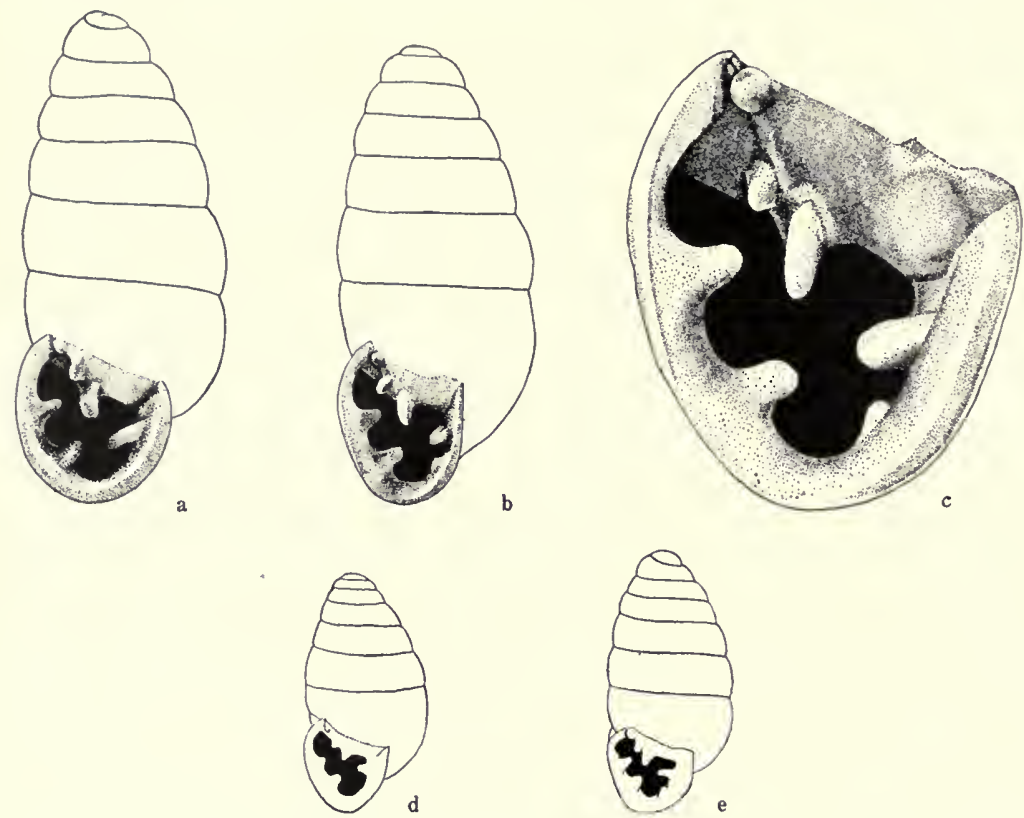

FIG. 98. Jaminia (Jaminia) chondriformis Mousson. a, length $6.7 \mathrm{~mm}$., typical specimen of normal size; Kariat Anawim west of Jerusalem; $\times 7.5 . \quad b$, length $6.4 \mathrm{~mm}$., conforming with $J$. massei Pallary; Wadi Ruwas, west of Jerusalem; $\times 8 . \quad c$, aperture of $a$, enlarged; $\times 20 . \quad d$, form of massei Pallary, length $4.8 \mathrm{~mm}$., dwarfed specimen; from Motza near Jerusalem; $\times 5$. $e$, dwarfed specimen of the typical form, length $5.5 \mathrm{~mm}$.; Shefeja, Mount Carmel; $\times 5$.

be clearly established. It may be added that the locality also supports this assumption, as will be shown later. None of Pallary's three figures show, however, the lower, small columellar tooth, referred to by Mousson as "infero basali obsoleto." When comparing a considerable number of specimens, I found this tooth either as a small prominence, or entirely wanting, in specimens from almost every locality, irrespective of the size of the individual. This is, no doubt, a variable character. Another variable feature, a small prominence at the angle between the callus and the columellar border, is, however, of rare occurrence. My drawings show specimens with six and with seven teeth, mostly $71 / 2-8$ whorls, color a 
transparent bright brown. The rim of the aperture and the teeth are pure white, the upper whorls dark brown.

Localities.- - Surroundings of Jerusalem (Mousson). For Pallary's Ch. Massei: Kariat el Enab (Qariat al Inab), $15 \mathrm{~km}$. west of Jerusalem.

The many localities where I found this species may be classed as follows: Surroundings of Jerusalem (Beth Hakerem, Lofta, Wadi Ruwas, Rechavia, Jefe Nof, Kfar Ivri, Gehennom, Motza); other places in the central hills (Qariat al Inab, Aquabella, Artuf, south of Bethlehem, Kfar Etzion, Wadi Kuff, Der esh Sheikj, Bab el Wad, Wadi Ghughab); Carmel region (surroundings of Haifa, Shefeja); Mount Gilboa.

It may be presumed that these localities will prove to be one continuous area of distribution in the hilly but not eremic portion of the country. We have no specimens from Upper Galilee, in spite of extensive collecting tours in this part of Palestine. It seems that the species is endemic in the central Judaean Hills, where it occurs rather frequently. It avoids the arid regions, even if they are rocky, and probably the northern part of the country. All the localities have a Mediterranean vegetation and no less than $400 \mathrm{~mm}$. of annual rainfall (Mount Gilboa); the Carmel area has about $800 \mathrm{~mm}$. From the central hills the species descends to the foothills (Bab el Wad, Artuf) but is not found in the coastal plain. It is frequent in the drift of the Jarkon River, but has not yet been found in that of the Jordan and the Jarmuk rivers. This points to a rather limited area of distribution. I found chondriformis frequently in thin layers of soil under or between compact blocks of Cenomanic limestone and under rather exposed smaller slabs of rock split off the exposed shales, or in the shade under boulders, in neglected terraces, but always in contact with rocks, of ten together with $J$. septemdentata, which is far more frequent.

According to Mousson, the size is $7 \times 2^{4} / 5 \mathrm{~mm}$. Pallary's $C h$. Massei measures $6 \times 21 / 2 \mathrm{~mm}$. I found specimens with a completely developed aperture no longer than $4.8 \mathrm{~mm}$. (fig. 98, $d$ ) and others up to a size of $6.7 \mathrm{~mm}$. (fig. 98, a). A specimen from Jerusalem of a length of $7.8 \mathrm{~mm}$. has no lower columellar tooth. There is, however, no indication of the existence of local dwarf or giant populations. Even the smallest specimens show the gradual conical enlargement of the whorls up to the antepenultimate. The shape of the aperture varies considerably. Not always do we find a straight columellar border (see fig. 98, $a, c, e$ ). The height-width ratio is very variable even in specimens from the same locality; the degree of development 
of the lower columellar tooth is not fixed either, so that it will be best to drop Pallary's species Massei.

Jaminia (Chondrula) septemdentata Roth. Figures 99, 100.

Pupa septemdentata Roth, 1839, Molluscorum species, quas in itinere per orientem facto comites clariss. Schuberti Doctores M. Erdl et J. R. Roth collegerunt, p. 19 , pl. 2, fig. 2.

Bulimus septemdentatus Pfeiffer, 1846, Symbolae ad historiam Heliceorum, 3: 57.

Bulimus ovularis Bourguignat, 1853, Catalogue raisonné ..., p. 41.

Chondrus septemdentatus Mousson, 1854, Coquilles terrestres et fluviatiles recueillies par M. le Prof. Bellardi dans un voyage en Orient, p. 46.

Buliminus septemdentatus Martens, 1874, Über vorderasiatische Conchylien, p. 26.

Chondrus septemdentatus Mousson, 1879, Jour. Conch. Paris, 22: 14.

Bulimus (Chondrula) septemdentatus Westerlund and Blanc, 1879, Aperçu sur la faune malacologique de la Grèce, p. 91.

Bulimus (Chondrus) septemdentatus Tristram, 1884, The fauna and flora of Palestine, p. 190.

Buliminus (Chondrulus) septemdentatus Westerlund, 1887, Fauna ... lebenden Binnenconchylien, III, p. 45.

Buliminus (Chondrula) septemdentata Blanckenhorn, 1889, Nachr. Bl. Deutsch. Mal. Ges., $21: 84$.

Chondrula (Chondrula) septemdentata Germain, 1912, Bull. Mus. Nat. Hist. Nat., Paris, 18: 447.

Before discussing the varieties of this species, I should like to emphasize several peculiarities of its aperture that recur consistently in spite of the great diversity of other features characteristic of the varieties. The angular tooth is smaller than the columellar one and the palatal teeth. The two unequal parietal teeth tend to fuse. The right parietal tooth may or may not be linked to the tooth in the insertion. The columellar tooth is the strongest and the most prominent of all. Near the insertion there may be a slight inflection of the lip, which protrudes into the aperture as a shallow prominence (see form maxima).

According to Westerlund, four forms can be distinguished: typica, 8-11 $\times 4-5 \mathrm{~mm}$.; maxima Bourguignat, up to $15 \times 5 \mathrm{~mm}$.; borealis Mousson, smaller and slimmer, 9-10 mm.; elongata Roth, oviform, oblong, dark aperture with strong teeth, size not given.

Mousson distinguishes: "var. maximus Bourg.-T. major (long. 10-12, diam. 41/2-5 mm.), fusco-cornea, anfractu ultimo ad marginem albo, irregulariter rugoso, dentibus validis in labio interno valde prominente albo depositis" and "var. elongatus Roth-ovato-ob- 
longa, obscura; apertura et marginibus similibus illis praecedentis varietatis" and "var. albulus Mss.-T. minor (long. 8-9, diam. $31 / 2-4 \mathrm{~mm}$.), conico-ovata, nitidiuscula; anfractibus subconvexis; superis pallide corneis; ultimo breviore, albescente; apertura parvula, dentibus invalidis." Then, Mousson continues: "Ces deux formes (1 et 2 ) ne sont pas de bonnes variétés." In contradiction to this, Mousson stresses the validity of albulus as a "variety"; this suggests the possibility of reducing Buliminus triticeus Rossmaessler from Damascus to the rank of a variety of septemdentatus.

Westerlund, however, doubts that albulus even deserves the rank of a variety, whereas he admits triticeus to specific rank.

Germain adds the var. borealis Mousson (from Asia Minor) to his Syrian species, but does not change the other varieties; he reports that the varieties maxima and elongata may be found together with the typical form and mentions triticea as a species. Forms from 6 to $10.5 \mathrm{~mm}$. in length are considered as var. typica.

Pallary (1929) adds a forma minor (8-8.5 mm.) from Beyrouth and regards Chondrula libanica Naegele (see Germain, 1922, p. 296) as a variety of septemdentata. He (1939, p. 47) mentions specimens of greater size than the typical forms from Bethlehem, introducing them in the beginning as "var. albina" but hinting later that this may be identical with maxima. He ends by naming it var. producta.

The value of most of these "varieties" seems very doubtful, if they are not connected with data of geographical or ecological significance.

The difficulties in the taxonomy of the dextrorse Chondrulae with seven denticulations are even more aggravated when the socalled "good" and "established" species related to septemdentata are taken into consideration. Jaminia ovularis may but need not be separated; the same holds true of $J$. heptodon. It seems justifiable to consider these as separate species, because, at least in Palestine, they are ecologically and geographically distinguishable.

Localities.- This species covers a very wide area and is always found in great numbers. Since a detailed list of all the localities represented would be a long one, it seems more convenient to name the regions where septemdentata never occurs: In shifting sand dunes along the Mediterranean coast; deep soil void of stones or rocks of any type; the basaltic area (Jordan Rift Valley). As a rule, this Rift Valley, up to the Gulf of Aqaba, and the arid South of Israel, the Negev, are free of any form of septemdentata, but $J$. heptodon takes its place on rocky ground, even under very arid conditions. 
On fixed dunes, especially in deeper layers of sandstone, J. ovularis and sulcidens are typical representatives of this genus. It can be said without exaggeration that a formation of limestone providing shelter among broken boulders, and a certain minimum of annual rainfall, are the prerequisites of a potential home of this species. The border of distribution follows approximately the isohyet of 400 $\mathrm{mm}$. annually, with the exception of the giant race from the central Negev, to be discussed below.

According to Germain, this species has a wide range in the Lebanon and the Antilebanon and in Asia Minor. Next to nothing is known concerning Transjordan; its northwestern regions of higher elevation certainly offer adequate living conditions. I found no specimens of septemdentata south of Amman, along the main road to Mecca, or in the surroundings of Jerash, in spite of apparently adequate conditions in the biotype.

Description.-A rather stereotyped configuration of the shell aperture is combined with extremely variable shape and proportions, as the ratio between the heights of aperture and shell or total width to total length is $1: 1.5-1.3$. On the other hand, the type of aperture provided with seven teeth in identical arrangement is also characteristic of heptodon, ovularis and sulcidens. Different ecological requirements and characters of the shell justify maintenance of these forms as valid species.

In spite of the extensive range of septemdentata, it is not easy to outline the characteristic features of typical populations restricted to minor areas. Rather large populations seem to occur in the Carmel area and at the western border of the Judaean hills. One of these "maxima" forms of $13.7 \mathrm{~mm}$. length from Mount Carmel is shown in figure 99, $a, b$. Rather large specimens occur, under much drier conditions, as far south as to the Gaza hinterland and in the central Negev (Wadi Abyed, Wadi Biqatel Amrin, Ras Raman [fig. 99, c]; Wadi Abda [fig. 99, $d, e$ ]; Wadi Gazza [fig. 99, $f-h$ ]), in regions occupied by the much smaller and more slender J. heptodon. The giants from the northern parts, as from the Carmel and the western border of the central hill range, live under relatively favorable conditions of precipitation and atmospheric humidity. This cannot be claimed for the southern giants, which seem to deserve at least subspecific rank with more justification than the rather vague varieties of the older authors, which often represent nothing more than extremes of size groups. Among the southern giants, two types may be distinguished. The first is very elongate. It is found in Wadi Gazza, Wadi Abyed, Wadi Biqatel (figs. 99, $f-h, 100, a$ ). 

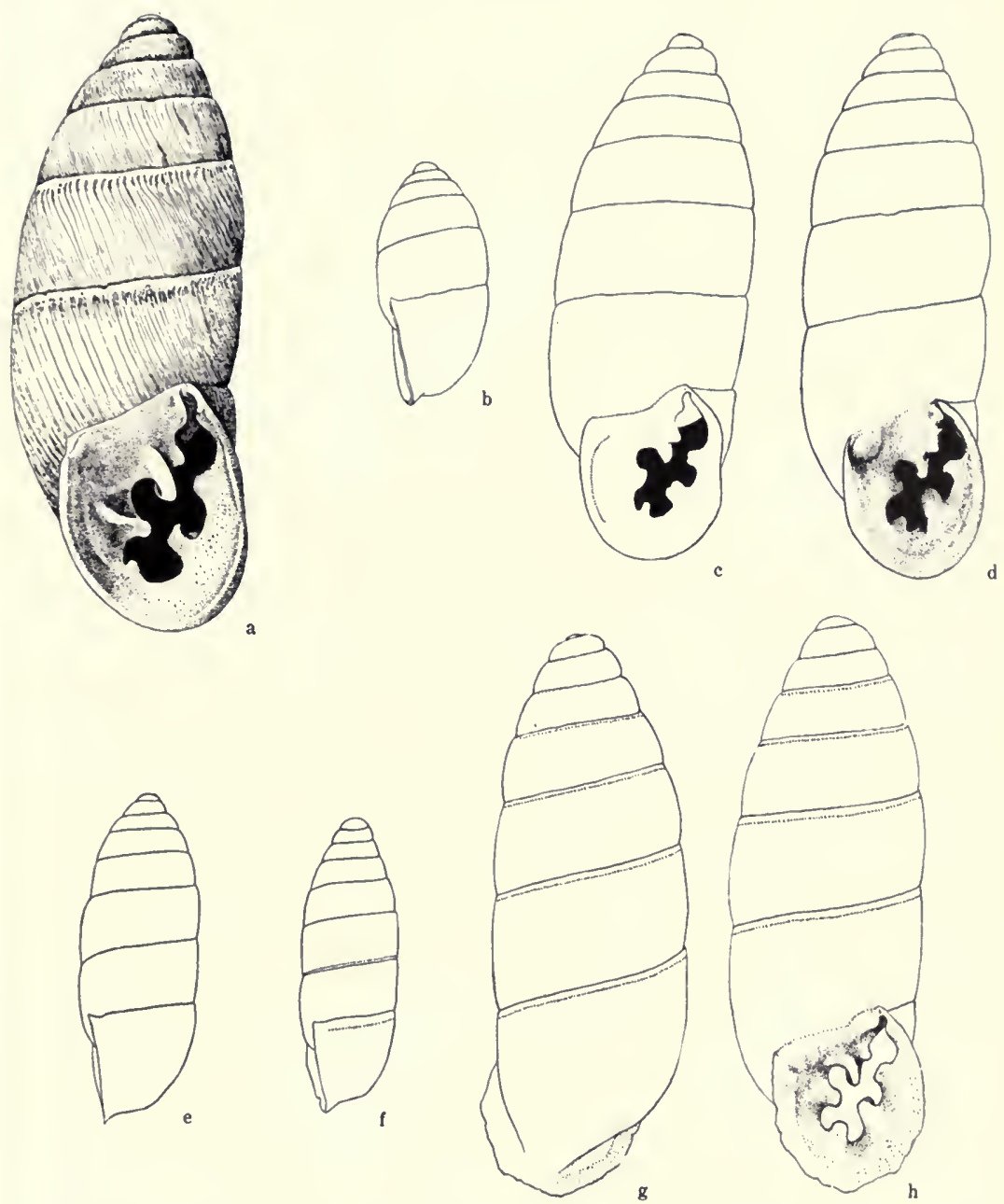

FIG. 99. Jaminia (Chondrula) septemdentata Roth. a, form "maxima,"length $13.7 \mathrm{~mm}$., Mount Carmel; northern giant; $\times 5$. b, "maxima," length $11.6 \mathrm{~mm}$., from Ahuza near Haifa; $\times 2.25$. $c$, stouter type of the southern giants, 14.6 mm., Ras Raman near Naqb el Arud; $\times 4$. $d$, emaciated type of the southern giants, length $15.1 \mathrm{~mm}$., Wadi Abda, southern Palestine; $\times 4$. $e$, same type, from Wadi Abda, length $14.9 \mathrm{~mm}$.; $\times 2.25$. $f$, same type, from Wadi Gazza (or Ghuzze), length $13.7 \mathrm{~mm}$; $\times 2.25$. $g, h$, same specimen; $\times 5$. 
Color of shell, with the exception of a small white area beyond the peristome $(2-3 \mathrm{~mm}$.) a bright brown; peristome white, suture as well. The prominent vicinity of the aperture from the umbilicus to the expanded lip, chalky white; eight to nine whorls. The shell is rather cylindrical. The last four to five whorls are not at all ventricose. The ratio of shell length to height of aperture is $3.25-1$; length of shell up to $14 \mathrm{~mm}$. The two parietal teeth sit on a common socket. The calliform tooth at the insertion is flat and padlike, but not prominent; pure white on brown background. The lower palatal tooth is slightly bifid at its summit.

The second type of the "southern giants," represented from Ras Raman and Wadi Abda, is stouter and its aperture is relatively bigger and broader (fig. 99, $c, e$ ).

Specimen from Wadi Abyed (first group): $13.5 \times 4.5 \mathrm{~mm}$., aperture $4.4 \times 3.3 \mathrm{~mm}$.

Specimen from Wadi Abda (second group): $13.7 \times 5.3 \mathrm{~mm}$., aperture $4.8 \times 4 \mathrm{~mm}$.

By comparing these two specimens of equal length, the striking difference in proportions becomes obvious. Figure 99, $d$, shows a somewhat abnormally elongate specimen of $15.1 \mathrm{~mm}$., figure $99, c$, a more typical one of stout proportions from Ras Raman. Many specimens of the second group show a callous thickening also at the columellar margin of the aperture, but it is less developed than the blunt tooth at the other end of the apertural callus.

Since it appears premature to apply a rigid classification to the various geographical races in our restricted area, I prefer for the time being to refer to them by number, such as population no. 1 from Wadi Gazza, etc.; no. 2 from Wadi Abda, etc.; no. 3, the long, darker specimens from the Carmel and the western foothills of the central Judaean range.

In all the other populations, representing the forms of smaller size, the apertures are relatively much bigger, and the insertion tooth is more prominent, not flattened. The lower palatal tooth is not cleft; seven whorls are the rule. The shell has a dark brown coloration.

A geographically isolated population, no. 4, of dwarfish specimens, occupies the southeastern border of the Lake of Galilee and the slopes of the Jarmuk gorge (El Hamme), as far as known (fig. $100, b)$. Specimens of this small type may be found frequently in the drift of the lower Jordan, the Jarmuk, and the Dead Sea. They consist mostly of only six whorls; their color is darker than in popu- 
lations 1 and 2 , but paler than in 3 . The upper whorls are mottled with black; the aperture as well as the lip and the contiguous end of the last whorl, about $1.5 \mathrm{~mm}$. wide, are white. The penultimate whorl is widest. Size 7-9 $\times 3.25-4 \mathrm{~mm}$. The longest specimens of
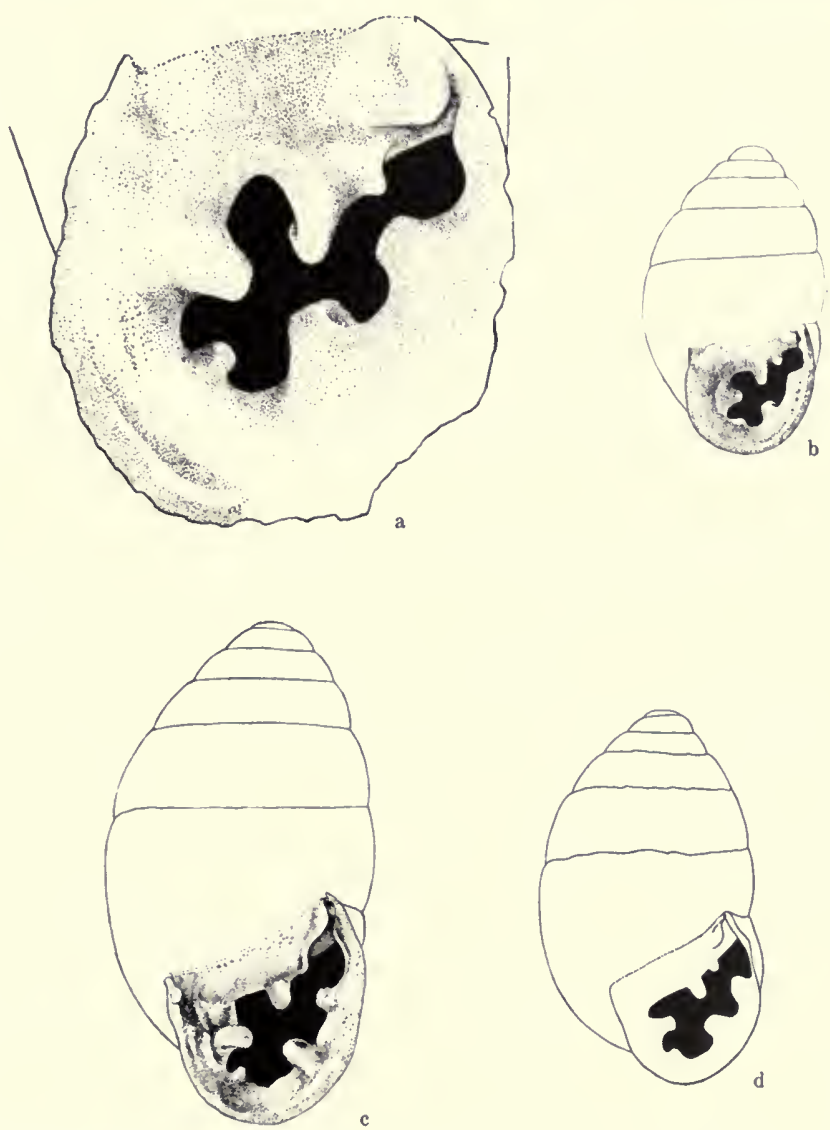

FIG. 100. Jaminia (Chondrula) septemdentata Roth. a, aperture of specimen shown in figure $99, g$, enlarged; $\times 10 . \quad b$, length $6.6 \mathrm{~mm}$., drift at north end of Dead Sea, dwarfed; $\times 5$. c, length $8 \mathrm{~mm}$., Mount Canaan, Upper Galilee, small globular form; $\times 6.5$. $d$, length $10.9 \mathrm{~mm}$., Jerusalem-Beth Hakerem, globular form of normal size; $\times 5$.

this population have a deepened suture and all the whorls are, thus, obese; the aperture is not very expanded and is rather high. The smallest specimens of this type $(6.8 \times 3.8 \mathrm{~mm}$., even smaller $)$ occur in steep wadis cut into sandstone at the southeastern part of the 
Lake of Galilee. These forms bear a striking resemblance to the still shorter and more globular species, Jaminia ovularis, which occurs in the coastal area of fixed dunes and sandstone. The occurrence of an almost ovularis-like form in the area of typical septemdentata shows clearly that the two species must be closely related, if not conspecific, the rock-dwelling septemdentata being capable of degenerating into a dwarfed form on the very permeable sandstone.

The limestone hills of central Palestine and the hills of Galilee and the Carmel are densely populated by the typical globular-ovoid forms (fig. 100, $c, d$ ). These have a rather dark shell; the penultimate whorl is the largest of the ventricose whorls. In higher, more exposed places, as on top of Mount Canaan in Upper Galilee, the globular type is represented by shorter shells than it is, for example, in the surroundings of Jerusalem. On Mount Gilboa, in Tiberias, and in certain localities in Upper Galilee, a somewhat more elongated type is found; in this form the parietal teeth do not have a common socket.

We may, therefore, distinguish the following types: no. 1, giant, slender, cylindrical forms, from Wadis Abyed and Gazza; no. 2, giant, cylindrical, but stouter types, from the central Negev; no. 3 , "forma maxima" of earlier authors, from the western slope of the central hills and from Mount Carmel; no. 4, dwarfs, from the eastern border of the Lake of Galilee and close-by points; no. 5, the typical form of medium size and more or less globular shape, from the central hills, Upper Galilee, and, partly, from the Carmel.

Discussion.-As a widely distributed species, Jaminia septemdentata shows clear tendencies to split up into races. The "varieties" of the older literature, especially maxima and elongata, are rather meaningless, because they have no geographical or ecological bearings. The proposed division of the species into five groups is an attempt to allot certain somatic types to specific areas. Only group 5 is sufficiently defined; it is found over a large area whose biotopical uniformity favors a moderate uniformity of the shells. Even collections from a very limited area show a certain degree of individual variation, probably due to differing microclimatic conditions.

The fact that very large types occur also in the more arid parts of the country (150-200 mm. of rainfall annually), whereas types 3 and 5 show an obvious correlation between shell size and relative humidity as expressed by the annual amount of rainfall, seems to point to the possibility of ascribing at least subspecific rank to the 
"giants" of the South. Study of their anatomy and cytology might clear up this question. We have to keep in mind that these giants live together with the much smaller Jaminia heptodon, which looks like a pale replica of Jaminia libanica, and that the two are widely separated both geographically and ecologically, the second being adapted to the highest amounts of rainfall in the entire Levant area (over $1,000 \mathrm{~mm}$. annually). J. libanica lives along the northern frontier together with septemdentata of our group 5, and the two are quite different. As this coexistence proves systematic independence in both cases, Jaminia libanica is certainly not a subspecies. Coexistence of the southern giants with any other form of septemdentata is not known, so far, and is very improbable. All these facts indicate a subspecific rank of these outstanding forms.

The forms referred to Jaminia septemdentata live, moderately hidden, under boulders and rocks in the limestone area and may be found in cracks and recesses of the rocks not quite as deep and shaded as the retreats of other rather hygrophilous species of the area, such as Granopupa rhodia and the species of Pene and Paramastus. During the wet season they gather under flat stones and emerge even during daytime on shaded surfaces of rocks. Young stages may be found shortly after the first rains in November, before the heavy rainfall of January and February.

Typical sizes of the five groups of Jaminia septemdentata (measurements in millimeters):

\begin{tabular}{|c|c|c|c|c|}
\hline & Height & Width & $\begin{array}{l}\text { Height of } \\
\text { aperture }\end{array}$ & $\begin{array}{l}\text { Width of } \\
\text { aperture }\end{array}$ \\
\hline No. 1 (Wadi Abyed) & 13.7 & 4.5 & 4.4 & 3.3 \\
\hline No. 2 (Ras Raman). & 14.7 & 5.3 & 5.0 & 4.0 \\
\hline No. 3 (Mount Carmel) & 13.7 & 5.0 & 5.2 & 4.0 \\
\hline $\begin{array}{c}\text { No. } 4 \text { (Ein Gew, east border } \\
\text { of Lake of Galilee) }\end{array}$ & 7.0 & 3.7 & 3.1 & 2.8 \\
\hline $\begin{array}{r}\text { No. } 5 \text { (Kfar Ivri, } 10 \mathrm{~km} . \\
\text { north of Jerusalem) .. }\end{array}$ & 10.2 & 5.1 & 4.2 & 3.7 \\
\hline
\end{tabular}

Jaminia (Chondrula) heptodon Martens. Figure 101.

Buliminus heptodon Martens, 1885, S. B. Ges. Naturf. Fr. Berlin, 1885: 88. Buliminus (Chondrula) heptodon Westeriund, 1887, Fauna...lebenden Binnenconchylien, III, p. 47.

Buliminus (Amphiscopus) aegyptiacus Westerlund, 1887, op. cit., p. 56.

Chondrulus heptodon Pallary, 1901, Bull. Inst. Égyptien, 2: 242, fig. 7.

Chondrula heptodon Kobelt, 1903, Iconographie... (N.F.), 10: 36-37, pl. 283, fig. 7; Pallary, 1909, Mém. Inst. Égyptien, 6: 40, pl. 3, figs. 7, 8.

It is not easy to define the differences between this species and septemdentata. There is no clear difference in the disposition of the 
apertural teeth, and the number is the same in both cases-seven. However, the shell is of rather more slender proportions, and the first whorls increase in a more conical shape and are more swollen in heptodon; the last whorl and the aperture are relatively lower in relation to height. The shell has a whitish or slightly yellowish color in living specimens, the apex always being darker than the bright lower whorls; this chalky color is shared by all extremely xeric pulmonates. As in septemdentata, the number of whorls varies between six and eight.

Thus there is an obvious difference in the ratios of height of aperture to total length, in color, and in configuration of the spire, which has a more elongate form and more swollen whorls in heptodon. Correlated with these differences is the ecological limitation to the sun-scorched desert habitat, often quite exposed gravel- or boulderstrewn flats or mounds in southern Palestine, and in adjacent spots of Sinai and Egypt (original locality!). The species is strictly linked to limestone deserts in the whole area.

Localities.-This species, which is here recorded for the first time from southern Palestine, was originally known from Egypt (Pallary, 1909, p. 40: Mariout, Port Said, Djebel Galala; Pallary, 1924a, p. 19: Djebel Hellal, Sinai Peninsula). It is normally 11-12 mm. long. Two "varieties" have been described: var. obesula (Pallary, 1924b, pp. 212-213), Djebel Yellag, Djebel Libni, Djebel Hellal, $8 \times 3.5 \mathrm{~mm}$. long; and var. minor (Pallary, 1924b, pp. 212213), from North Sinai, 8.25-3.25 mm. long. "Espèce découverte par Schweinfurth à Port Said et sur le littoral de la Mer Rouge. Sa dispersion s'étend donc du Nile à l'Arabie Petrée." From the region of the Sinai Peninsula this species penetrates into the south of Palestine (the Negev), where it is very abundant in the rocky desert and on level ground covered by boulders and heat-cracked stones. In these arid regions pure loess and loose sands are avoided by this species; in this way the Mediterranean coastal area of Palestine is strictly excluded from its range. In the HUJ collection there is a very great number of specimens from many localities, ranging from the southern surroundings of Beer-Sheba toward the Sinai border to the West, and toward the Wadi Araba up to the south end of the Dead Sea to the East. It may be taken for granted that this species and the loess-living helicid snail Sphincterocheila boissieri are the most frequent and characteristic mollusks of the arid south of Palestine.

Discussion.-Pallary separates from the typical form a var. obesula $(8 \times 3.5 \mathrm{~mm}$.; Djebel Hellal) and a var. major (Sinai Penin- 
sula; $11-12 \mathrm{~mm}$.$) . He adds a var. minor (8.25-3.25 \mathrm{~mm}$.) from northern Sinai. Our collections, restricted to southern Palestine, contain samples that agree with each of these size classes (there is certainly no more intrinsic value in these "varieties"), specimens from 12
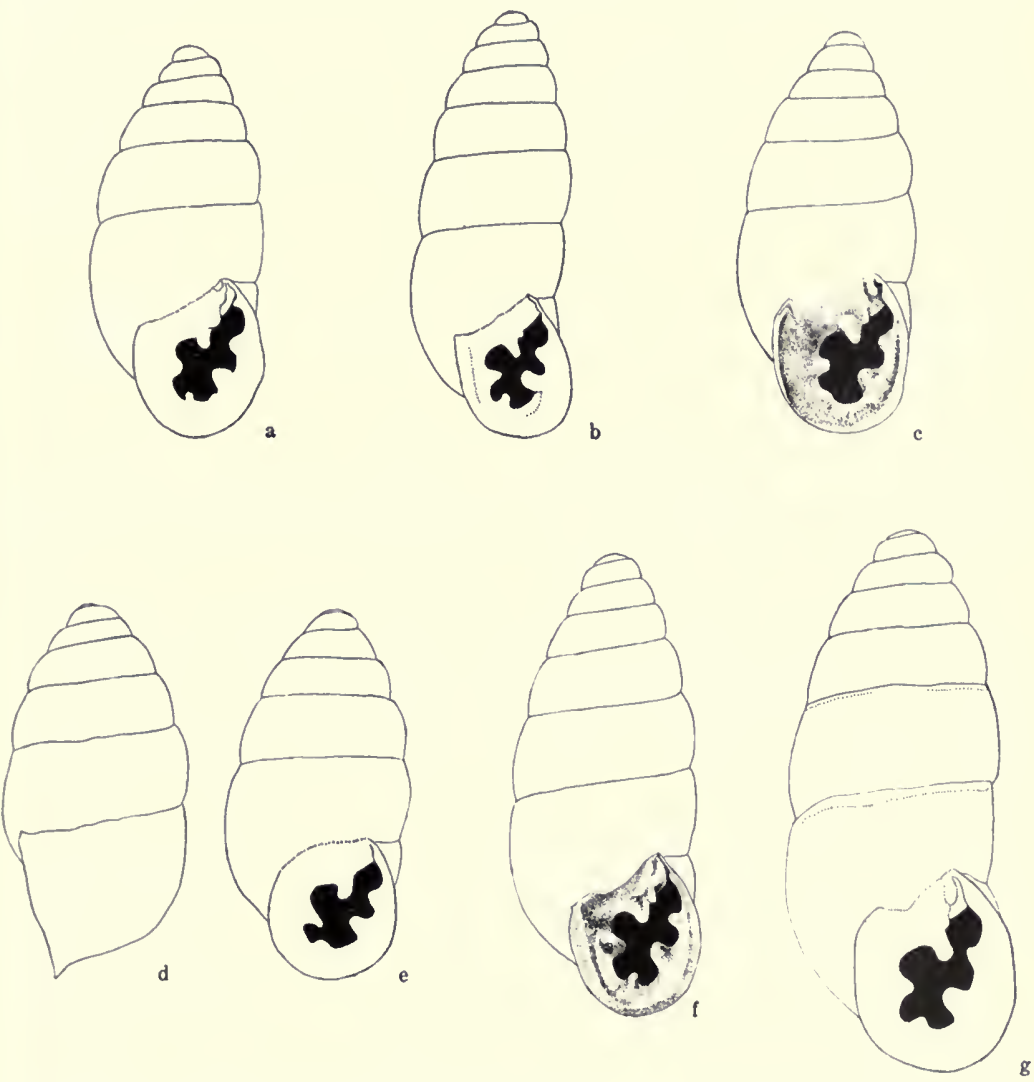

FIg. 101. Jaminia (Chondrula) heptodon Martens. a, length $9.7 \mathrm{~mm}$., Ras Raman, Naqb el Arud; $\times 4.5$. $b$, length $11.8 \mathrm{~mm}$., Wadi Raman, southern Palestine; emaciated large form, corresponding to Pallary's var. major; $\times 3.6 . \quad c$, length $8.5 \mathrm{~mm}$., drift of Dead Sea at Kallia; $\times 4.8$. $d$, $e$, length $7.5 \mathrm{~mm}$., Kurnub, southern Palestine; corresponds to var. obesula Pallary; $\times 5$. $f$, length $7.8 \mathrm{~mm}$., Khosseime, southern Palestine, border of Sinai; $\times 6$. $g$, length $9.4 \mathrm{~mm}$., Wadi Nefkh, southern Palestine, referable to var. major Pallary; $\times 5.75$.

$\mathrm{mm}$. down to $7.8 \mathrm{~mm}$. being represented in these series, all with intermediate lengths; the size variability even in material from very restricted areas is really striking. I found no geographically fixed populations of smaller or larger types, and the same may be said 
of the relative and the absolute width of the shells; for example, together with specimens from the Wadi Nefkh of $9.4 \mathrm{~mm}$. length, another of less than $7 \mathrm{~mm}$. was found; together with excessively elongate specimens from the Wadi Raman (11.8 mm., fig. 101, b), there occurred others of only $7.3 \mathrm{~mm}$.

Remarks.-According to Pallary (1909), Chondrula heptodon Martens, 1885, is synonymous with Buliminus (Amphiscopus) aegyptiacus Westerlund, 1887. As far as our collections indicate, no intermediate forms bridging the gap between septemdentata and heptodon seem to exist.

Jaminia (Chondrula) libanica Naegele. Figure 102.

Buliminus (Chondrulus) libanicus Naegele, 1897, Nachr. Bl. Deutsch. Mal. Ges., 29: 14 .

The arrangement of the seven apertural denticulations in this species resembles that found in septemdentata, but the aperture is less expanded, rather triangular, and smaller in relation to the height of the shell. As a rule, the basal tooth is very feebly developed; there are seven to eight whorls, length of shell $5.5-7 \mathrm{~mm}$., width $3 \mathrm{~mm}$. The rather slender, elongate shell gradually increases in width up to the penultimate whorl. The whorls are rather swollen. The shell has a dark reddish-brown coloration, the peristomial border is whitish outside and inside, and the teeth are white; the upper side of the aperture is brown, as is the rest of the shell.

Several species closely resemble this form. The specimen of libanica figured by Germain (1922, pl. 15, figs. 20, 21) measures 6-6.25 $\times 2.8-6.3 \mathrm{~mm}$.; many of our specimens are slightly longer, but others-all chosen from the same locality-measure only 5.5 $\mathrm{mm}$. in length.

Chondrula florieni Pallary (1929, p. 23, pl. 1, figs. 33, 36) seems to be rather similar to libanica. Unfortunately, the two little prominences above the parietal tooth cannot be distinguished in the figures; they show, however, a variable degree of development in our specimens of libanica and are clearly visible in Germain's figure of this species. Another form, described by Bourguignat as Pupa michoni and called Chondrula (Amphiscopus) michoni by Germain, has aroused some doubt, since specimens from the type locality ("environs du Lac de Tibériade, sur les rochers qui avoisinent le lac du même nom") may be referred to the same type of libanica. However, it seems to me that the figure of this form (Bourguignat, 1853, p. 53, pl. 2, figs. $24-25, e$ ) is not correct, because it does not show the very 
small prominence between the parietal tooth and that near the insertional border: the columellar tooth is bent slightly downward in my specimens from the same locality (fig. 102, $a, b$ ), a bit more so than in specimens from other localities (fig. 102, c-e). I think, therefore, the best solution is to cancel either libanica or michoni.
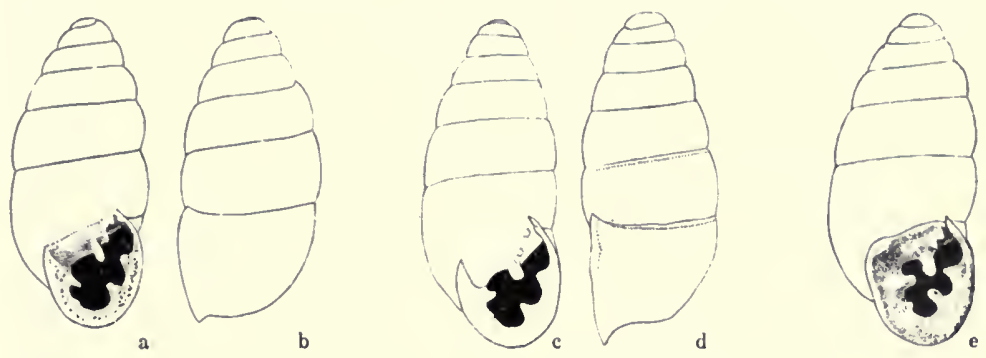

FIG. 102. Jaminia (Chondrula) libanica Naegele. $a$, b, length $6.7 \mathrm{~mm}$, Migdal, shore of Lake of Galilee. $c$, d, length $7 \mathrm{~mm}$., Wadi Rushmie near Haifa. $e$, length $6.6 \mathrm{~mm}$., Wadi Karkara, Lebanon frontier. All $\times 5$.

Localities.-Migdal, shore of Lake of Galilee (fig. 102, $a, b$ ); Wadi Rushmie, Carmel, near Haifa (fig. 102, c, d); Wadi Karkara (fig. 102,e); and Wadi Qarn, both in northern Palestine. Germain mentions the following localities: Haman, Lebanon (1,000 meters), environs of Beyrouth.

The species occurs in the northern part of Palestine and ranges from there into the Lebanon. It is found on limestone rocks only. The biotopes, with the exception of the Lake of Galilee, have the highest amount of rainfall occurring in Palestine. Like many other northern species of the area, libanica does not penetrate into the central hills south of the Carmel massive, just like Pomatias olivieri, Euxina moesta, and other forms among the land mollusks. The fact that this small species lives side by side with Jaminia septemdentata proves beyond doubt that we are dealing with two "good" species.

Discussion.-The different populations show slight differences. In specimens from the Wadi Karkara the aperture is excessively narrowed by the teeth, and the peristomial border is rather strongly developed. In specimens from the Wadi Rushmie, Migdal, and the Wadi Qarn the peristomial rim is narrower. The basal tooth presents all degrees of reduction, thus possibly bridging the gap that separates this form from Jaminia sexdentata Naegele. Concerning the two tubercles above the parietal tooth, the same diversity seems to prevail, even in one and the same population. Often the lower 
tooth is almost invisible and exists merely as a whitish spot; the "species" michoni was probably founded on such a form. The most peculiar feature of this species is its similarity to certain small specimens of Jaminia heptodon, which is, however, ecologically and geographically well separated. No wonder, therefore, that certain specimens belonging to heptodon were classified, many years ago, by a well-known Viennese malacologist, as septemdentata septemdentata $\rightarrow$ septemdentata libanica. But libanica is always dark brown, heptodon always very light and whitish on the last whorls and yellowish brown on the earlier whorls. There is also, in general, a difference in size proportions, heptodon being the larger form with a rather more conical apical region, whereas the smallest heptodon measure about $7.8 \mathrm{~mm}$. and the largest libanica have a length of only 7.0 $\mathrm{mm}$. There is no overlapping in size, as far as the Palestinian material is concerned.

The identity of Jaminia libanica Naegele with Pupa michoni Bourguignat is very probable; if it is proven, the name michoni of 1853 has priority over libanica, which dates from 1897. There can be no doubt that Pallary's species Chondrula florieni and Rossmaessler's Bulimus lamelliferus are very close relatives, if not merely local variants of this type of small, seven-toothed, dark-brown Jaminia. As will be shown later, there are yet other forms of similar size and structure that do not correspond exactly to the species thus far described.

Jaminia (Chondrula) lamellifera Rossmaessler. Figure 103.

Bulimus lamelliferus Rossmaessler, 1859, Iconographie..., 3: 95, pl. 83, fig. 919.

"Petite espèce, très ventrue-globuleuse, haute de $6.5 \mathrm{~mm}$., large de $4.5 \mathrm{~mm}$., pourvue d'un ombilic bien ouvert, en fente oblique. Le test est obliquement et un peu fortement strié." In this way, Germain (1922, pp. 297-298) characterizes this species, while Mousson (1861, pp. 47-48 of reprint) describes it as follows: "Le $B$. lamelliferus Rssm. se distingue (du Ch. ovularis Oliv.) par sa grosse dent dorsale unique, prolongée en crête."

In the drift at the north end of the Dead Sea at Kallia I found one specimen that may be referred to this species, since it has only one parietal tooth and a very slight protuberance at the insertion, and only six whorls (fig. 103, a). The parietal tooth, however, is not prolonged inwardly. The rather globular shape of the shell makes it look like ovularis. Probably this specimen is of northern 
origin, somewhere from the headwaters of the Jordan or its affluents; ovularis is restricted to the coastal plain of the Mediterranean. Since other specimens of similar size and proportions found at the same place show the typical intermediate tooth and the inserted tubercle in various degrees of rudimentation, corresponding, there-
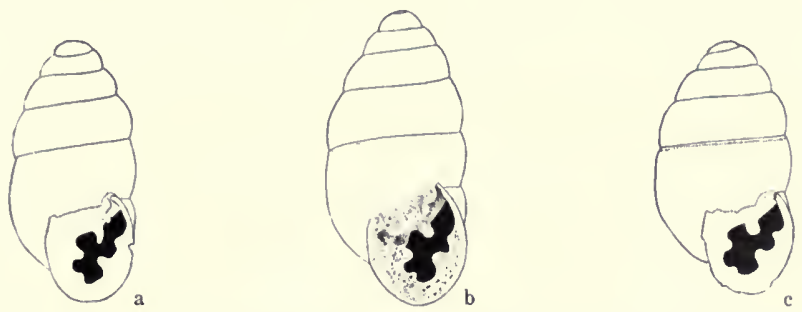

FIg. 103. Jaminia (Chondrula) lamellifera Rossmaessler. $a$, length $5.5 \mathrm{~mm}$, drift of Dead Sea at north end, at Kallia. b, length $6.0 \mathrm{~mm}$., drift of Jordan immediately before it empties into the Dead Sea. $c$, length $5.3 \mathrm{~mm}$., drift of Dead Sea at north end, at Kallia. All $\times 5$.

fore, to small specimens of $J$. libanica, the possibility of an individual variant must be considered (fig. 103, $b, c$ ).

Remarks.-Intergradation between $J$. libanica and J. lamellifera seems rather probable. Since $C h$. florieni Pallary is apparently no more than a libanica with very minute or completely reduced upper parietal and insertional teeth, I advise caution about this species. There seems to be an ill-defined group of dark-brown, small (6-7 $\mathrm{mm}$.), rather elongate forms with six swollen whorls, exhibiting different degrees of reduction of the upper two denticles. There are the following possibilities concerning the differentiation of the small teeth, or, better, prominence, at the insertional border: in libanica two almost vertically superposed "teeth" are present; in lamellifera only a single, blunt one is developed. In Pallary's photograph of florieni, no denticles are visible at this spot. However, the species lamellifera is, probably, not unequivocal; Germain figures an aperture of a J. lamellifera bearing, at the external border and following the small basal tooth, one very obvious lower prominence, followed by an extremely blunt one higher up. Specimens in the British Museum (Natural History) collections from the Dardanelles and the Caucasus have two equally low denticles above the large one at the external wall of the aperture. By comparison of these data with the rather meagre descriptions quoted at the beginning of this paragraph, I feel that an exact description of this species is still wanting. The three specimens figured here under the name lamellifera (fig. 103) 
comply more or less with the first two descriptions by Germain and Mousson. All three bear only one minor external tooth; however, with the exception of the specimen shown in figure 103, $c$, two superposed tubercles are found at the insertional border. Taking into account their shape, their six whorls and their minute size, I am inclined to consider them as rather aberrant variants of lamellifera. In Palestine, all these ill-defined small Jaminiae are restricted to the north, penetrating somewhat into the northern central hills.

Jaminia (Chondrula) sexdenta ta Naegele. Figure 104.

Buliminus (Chondrus) sexdentatus Naegele, 1897, Nachr. Bl. Deutsch. Mal. Ges., 29: 13.

This species, according to Germain (1922), is "voisin de Ch. septemdentata Roth ... il s'en distingue surtout par son ouverture garni seulement de six denticulations: 1 pli pariétal robuste, 1 pli à l'insertion du bord supérieur, 1 pli columellaire et deux plis sur le bord externe de l'ouverture." Size $8 \times 3 \mathrm{~mm}$. According to Pallary (1924a), this species is smaller and more elongate than septemdentata and has six teeth, a basal tooth being absent. Pallary's figures (pl. 1, figs. 31, 32) show a rather slender form of $8 \times 3.5 \mathrm{~mm}$. The details of the insertional region are not quite distinctly visible; if, as this author says, the only difference between septemdentata and this species consists in the missing basal tooth, the name of sexdentata is appropriate. Germain, however, speaks of five teeth only, for there is one "pli" at the insertion. Both the text and the figures in Pallary speak for conditions as in septemdentata. I saw specimens in the British Museum from the Lebanon that confirm this identity, as well as specimens in which the basal tooth is missing.

The taxonomy of this group is not clear, as will be seen in the following paragraphs. In Palestine proper, forms of the habitus and size as quoted above have not been found. But there are in the HUJ collections two specimens (fig. 104, $a, b, e$ ) with eight whorls, without a basal tooth, but with very weakly developed denticles at the insertional border; they are much more slender than typical sexdentata and measure only 7-7.3 mm. in length. The specimen from the deposits of the Jarkon River (fig. 104,e) resembles also $J$. ghilanensis Issel from Transcaspia (specimens seen at the British Museum), but this latter one is a much larger form, measuring $11 \times 3.5 \mathrm{~mm}$., and has a far more remote area of distribution. It seems, therefore, more logical to connect these two specimens with sexdentata. The fresh specimen from Wadi Dallam in northern 
Palestine has a dark reddish-brown color (fig. 104, $a, b$ ). However, the difficulty increases, even with the fact that there are specimens like those in figure 104, $c$ and $d$, of $6.2 \mathrm{~mm}$. length only, with six whorls instead of eight, with a relatively higher aperture and a more ovoid-cylindrical shape (from the drift of the north end of the Dead
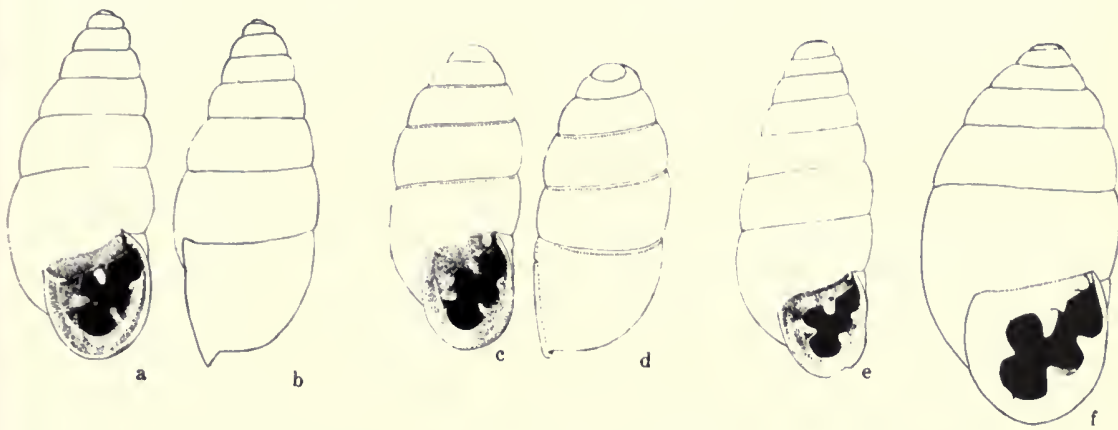

FIG. 104. Jaminia (Chondrula) sexdentata Naegele. $a, b$, length $7.3 \mathrm{~mm}$., Wadi Dallam, Upper Galilee. $c$, $d$, length $6.2 \mathrm{~mm}$., drift of Dead Sea at north end, at Kallia; smallest form. $e$, length $7.1 \mathrm{~mm}$., drift of Jarkon River. $f$, length $8 \mathrm{~mm}$., Sahle, Lebanon; globular, large type. All approximately $\times 5$.

Sea, at Kallia). They slightly resemble Pallary's $J$. louisi, which measures $6.5 \times 3 \mathrm{~mm}$. and has $61 / 2$ whorls. Our specimen is relatively narrower, especially the aperture, and has two little tubercles between the parietal tooth and the insertion; such a differentiation is lacking in louisi. Neither species has a basal tooth, but I prefer to consider the shell from Kallia also as a minute form of sexdentata, due to its closer similarity in general shell proportions to this species, and due to the presence of two insertional denticles. It seems not impossible that the "species" sexdentata has a double source, the large, ventricose Syrian forms being closely related to septemdentata. Figure 104, $f$, shows a specimen from the Lebanon (Sahle) that still has a faint indication of the basal tooth but is otherwise a typical septemdentata (length $8 \mathrm{~mm}$.). The narrow types as figured in figure 104, $a$ and $e$, may approach libanica, where the basal tooth is very often rather inconspicuous (see fig. 102). The general proportions of the shell and of the aperture correspond fairly well in both types. The specimen shown in figure $104, c, d$, however, remains rather isolated and certainly does not fit either trend, as it has six whorls only and quite different proportions and dimensions.

The biggest specimen of the Sahle series measures $8.7 \times 4.2$ $\mathrm{mm}$., the smallest $7.6 \times 3.8 \mathrm{~mm}$. 
A sexdentata-like form could have risen from a double source, from the smaller, more elongate libanica as well as from the bigger and more globular septemdentata. The two species coexist in the same biotopes of northern Palestine and the Lebanon. It is most probable that Naegele's and Germain's sexdentata belong to septemdentata, Pallary's specimens however to the libanica "ancestors." The first form is found in the northern Lebanon, the second one in Ghosta, Lebanon, 600 meters altitude. A taxonomic subdivision of sexdentata is, for the time being, not advisable.

\section{Jaminia (Chondrula) ovularis Olivier and Jaminia (Chondrula)} sulcidens Mousson. Figures 105, 106.

Bulimus ovularis Olivier, 1801-7, Voyage empire Ottoman ..., 2: 14, pl. 17, fig. $12, a, b$.

Chondrus ovularis Mousson, 1861, Vierteljahrschr. Naturf. Ges. Zürich, 6: 47. Chondrus ovularis var. sulcidens Mousson, 1861, Vierteljahrschr. Naturf. Ges. Zürich, $6: 48$.

Chondrula (Chondrula) ovularis Germain, 1922, Mollusques...de Syrie, p. 320 .

Both forms, ovularis (fig. 105) and sulcidens (fig. 106), represent the smallest Jaminiae found in the region; they are the minute, seven-toothed, globular, dextrorse representatives of the genus, and belong to the septemdentata group. I agree with Pallary in conceding full specific rank to Mousson's var. sulcidens.

$J$. ovularis is always the more globose form and has tubercular teeth; the knob at the insertion is very slightly developed. The aperture is less constricted than in sulcidens and the shell is darker brown. The average length ( 15 specimens measured) is $5.3 \mathrm{~mm}$., the average width $3.5 \mathrm{~mm}$.

$J$. sulcidens has a more elongate shell, with much more swollen whorls. Both palatal teeth are enlarged and more or less cleft at the summit. The basal tooth is stouter than in ovularis and the other denticles also are blunter and rather closely spaced around a very narrow aperture. In this respect the two forms differ strikingly. The color of sulcidens is somewhat brighter than that of the other species, and the shell thinner. The aperture is relatively higher: the insertional angle has shifted upward in sulcidens. Mousson says that the larger parietal and the upper columellar teeth are bifurcate as well, a peculiarity that is absent in our specimens, which almost invariably show the condition represented (fig. 106); very rarely, I found a cleft columellar tooth. There is also a marked difference 
in size (10 specimens measured): greatest length $4.9 \mathrm{~mm}$., greatest width $3 \mathrm{~mm}$. In contrast to septemdentata and similar forms, the insertional tubercle is wanting.

Both species are restricted to the coastal plain of Palestine. It is superfluous to list a long series of localities where these two forms abound. Germain mentions as locality for ovularis Beit-Méri in the Lebanon, 600-800 meters altitude; this is rather strange, since
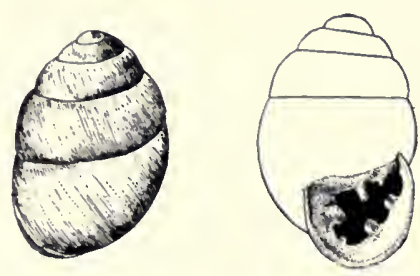

FIG. 105. Jaminia (Chondrula) ovularis Olivier. Length $5.3 \mathrm{~mm}$., Kfar Saba in the coastal plain; $\times 4.5$.
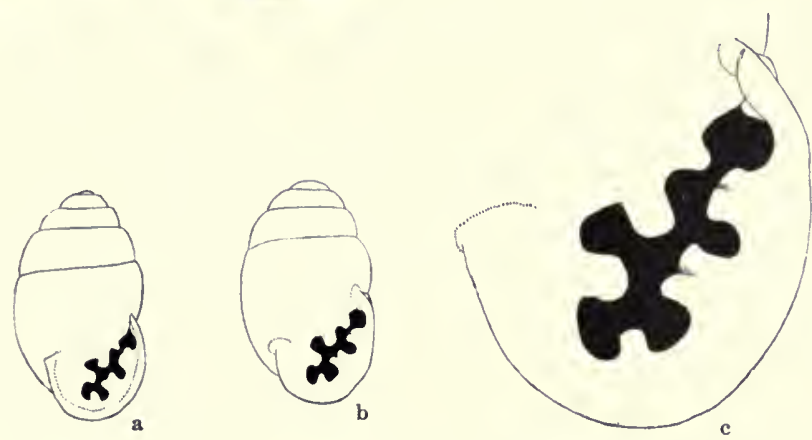

FIG. 106. Jaminia (Chondrula) sulcidens Mousson. $a, b$, length 4.7 and 4.8 mm., respectively; $\times 5$. $c$, aperture of $b ; \times 18$.

in Palestine this form is restricted to the coastal dune belt and the neighboring plains. $J$. sulcidens is found in the dune area proper, $J$. ovularis more inland. There is a slight possibility of a gradual transition to the smallest septemdentata forms, since we found in an inland sandstone area, east of the Lake of Galilee, a population of dwarfed J. septemdentata.

Both species have been found only in sandy regions and in the local, spongy sandstone (Kurkar), in one case near a dried swamp (Kabara) between the slopes of Mount Carmel and the seashore. In the dunes many empty shells are found in the deeper parts, where some vegetation remains; such spots are moister during the rainy season. 
Pallary's assumption that specimens found in Palestine must have been transported there from Egypt is erroneous, since many living specimens have been found in the coastal belt. The localities where we found both species, ovularis and sulcidens, extend from Haifa in the north to Gaza in the south. There is, therefore, an area of distribution from the Egyptian western desert (Mersa Matruh) up to the Lebanon. Probably sulcidens represents a type adapted to typical dune conditions, whereas ovularis favors an admixture of humus.

Typical ovularis from Kfar Saba, inland from the dune belt, have a height of 5.6-4.9 mm., and a width of $3.7-3.0 \mathrm{~mm}$. One single specimen from Doroth, east of Gaza, some $17 \mathrm{~km}$. from the nearest point of the coast, suggests the possibility of a transition to septemdentata (or heptodon?). There is no insertional tubercle, the number of whorls is six instead of seven, and the shell is more pointed at the apex than in ovularis. On the other hand, the smallest forms of heptodon measure $8 \times 3.5 \mathrm{~mm}$. ("obesula"), the smallest septemdentata $7 \mathrm{~mm}$. (G. Haas) or $8.25 \mathrm{~mm}$. (Germain). The Doroth specimen measures $6.2 \times 3.2 \mathrm{~mm}$. and is therefore of a size which does not fit any of the species possibly involved. J. sulcidens ranges from 4.2 to $5.5 \mathrm{~mm}$. in length and from 2.8 to $3.3 \mathrm{~mm}$. in width. These few instances show that a thorough analysis of the populations of the minute Jaminiae from the coast toward the foothills could help to elucidate the relationships of the various species.

Pallary (1909) remarks that Chondrus l'hotellieri Bourguignat must be referred to Jaminia sulcidens; this is also true of Ch. septemdentatus Roth, found at the Lake of Mariout, according to O. Fraas. As mentioned above, I gave preference to Pallary's view in granting sulcidens full specific rank. I think that the morphological and ecological differences between the two forms in question favor this opinion. Mousson, and later Germain, considered sulcidens as a variety of ovularis.

\section{OTHER SPECIES OF JAMINIA RECORDED FROM PALESTINE}

Various authors have mentioned other species of Jaminia as found in Palestine, but the collections of the HUJ do not contain them, since they have never been found again. They are as follows:

Jaminia tridens Müller var. langei O. Boettger.

Environs of Haifa, after Germain. 
Chondrula tricuspidata Küster.

Syria, near Beyrouth (now Lebanon).

Chondrula ghilanensis Issel.

Persia; Crimean Peninsula; Syria.

Chondrula limbodentata var. abbreviata Mousson.

Syria.

Chondrula broti Clessin.

Syria.

Chondrula triticea Rossmaessler.

Damascus (doubted by Pallary); Jerusalem.

Chondrula (Amphiscopus) ledereri Zelebor.

Taurus.

Chondrus septemdentatus var. albulus Mousson.

Jerusalem. Westerlund does not attribute even varietal rank to this form. According to the figures given by Pallary (1924a, pl. 1, figs. 48-51) and the description of it, I believe that it does not belong to septemdentata at all and that its identity with heptodon is far more probable.

Chondrula florieni Pallary.

Djebel Kassioun near Damascus.

Chondrula louisi Pallary.

Plain of Bekâa, east of Moallaka, Damascus.

I mentioned these last two species in discussing Jaminia lamellifera and J. libanica.

Chondrus saulcyi var. impressa Mousson.

This seems to me, also in accordance with the locality given - "Jerusalem"-nothing else than Jaminia chondriformis. I saw specimens of this form in the British Museum.

\section{APPENDIX}

Jaminia (Chondrula) sp. Figure 107.

It is with some hesitation that I add a short description of a very strange-looking specimen found in the drift of the Jarkon 
River near Tel Aviv, perhaps transported there from elsewhere by currents of the Mediterranean. The shell has the general type and proportions of the small $J$. lamellifera, but it has a very large columellar prominence with a long, straight, vertical border, and
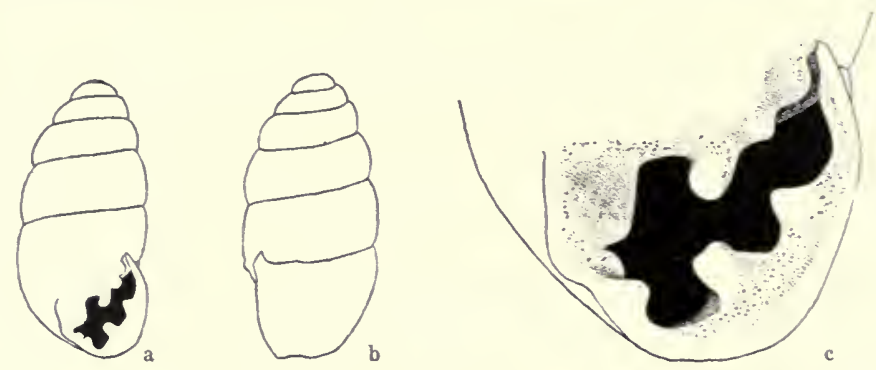

FIg. 107. Jaminia (Chondrula) sp. $a$, b, length $5.8 \mathrm{~mm}$., drift of Jarkon River near Tel Aviv; $\times 5$. $c$, aperture enlarged; $\times 16$.

beneath this massive excrescence two basal teeth of equal size, the upper one between the columellar tooth and the more externally inserted lower one, which is inserted more basally. All the other denticulations resemble in arrangement and proportions those of a normal septemdentata, but the lower palatal tooth shows a slight furrow on its summit. Size $5.8 \times 2.6 \mathrm{~mm}$., size of aperture $2.0 \times 1.9$ $\mathrm{mm}$. As only one specimen has been found, it cannot be decided if this should be considered a separate species or an individual abnormality of Jaminia (Chondrula) lamellifera.

\section{SUMMARY}

The genus Jaminia has a wide distribution in Palestine and shows an amazing variability in the various biotopes. The smallest forms live in dunes and sandstone areas, where there is strong percolation of water. Species of medium and larger sizes inhabit regions of limestone rocks. Probably due to differences in tolerance of temperature, Jaminia saulcyi occupies the north, J. septemdentata the north and the central hills, J. heptodon the arid southern region. Some "species" seem to have arisen diphyletically by convergent evolution, as, for instance, J. sexdentata; this assumption cannot be proved, however, at present. 


\section{REFERENCES}

\section{BOETTGER, OSKAR}

1883. Malakozoologische und palaeontologische Mitteilungen, II. Binnenconchylien aus Syrien. Ber. Offenb. Ver. Naturk., 22-23: 162-176, pl. 1.

\section{Bourguignat, Jules-René}

1852. Testa novissima quae $\mathrm{Cl}$. de Saulcy in itinere per orientem annis 1850 et 1851 collegit. $31 \mathrm{pp}$. Paris.

1853. Catalogue raisonné des mollusques terrestres et fluviatiles recueillis par M. F. de Saulcy pendant son voyage en orient. xxvi +96 pp., 4 pls. Paris.

\section{FORCART, LOTHAR}

1940. Monographie der türkischen Enidae (Moll., Pulm.). Verh. Naturf. Ges. Basel, 51: 106-263, 13 figs., pls. 1-3.

\section{Germain, Louis}

1922-23. Mollusques terrestres et fluviatiles de Syrie. 1: 523 pp., 56 figs. (1922); 2, 242 pp., 62 figs., pls. 1-23. In Gadeau de Kerville, Henry, Voyage Zoologique de ..., en Syrie (Avril-Juin 1908), 2 and 3.

\section{Mousson, Albert}

1861. Coquilles terrestres et fluviatiles recueillis par M. le Prof. J. R. Roth dans son dernier voyage en orient. Vierteljahrschr. Naturf. Ges. Zürich, 6: 1-34, 124-156 (reprint, pp. 1-68).

\section{Pallary, Paul}

1909. Catalogue de la faune malacologique d'Égypte. Mém. Inst. Égyptien, 6: 1-92, pl. 4 .

1924a. Supplément à la faune malacologique terrestre et fluviatile de l'Égypte. Mém. Inst. Égyptien, $7: 1-61$, pls. 1-4.

1924b. Faune malacologique du Sinai. Jour. Conch. Paris, 68: 181-217, pls. $10-12$.

1929. Première addition à la faune malacologique de la Syrie. Mém. Inst. Égyptien, 12: 1-43, pls. 1-3.

1939. Deuxième addition à la faune malacologique de la Syrie. Mém. Inst. Égyptien, 39: 1-141, pls. 1-7.

\section{Tristram, Henry Baker}

1865. Report on the terrestrial and fluviatile Mollusca of Palestine. Proc. Zool. Soc. London, 1865: 530-545.

\section{Westerlund, Carl Aghard}

1887. Fauna der in der palärktischen Region (Europa, Kaukasien,....) lebenden Binnenconchylien. III. Gen. Buliminus, Sesteria, Pupa, Stenogyra \& Cionella. $183 \mathrm{pp}$. Lund. 






UNIVERSITY OF ILLINOIS-URBANA

$590.5 \mathrm{FI}$

FIELDIANA, ZOOLOGYSCHGO

37-38 1955-56

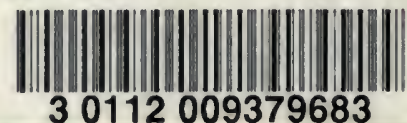

